\title{
Keunggulan Yesus Kristus Menurut Kolose 1:16-18
}

\author{
Stepanus \\ Sekolah Tinggi Teologi Kalimantan \\ Korespondensi: stepanus@sttkalimantan.ac.id
}

\begin{abstract}
Abstrak
Sejarah kehidupan jemaat Allah selalu mengalami hambatan dan cobaan, gereja ditantang dengan berbagai cara baik dari luar maupun dari dalam untuk menggagalkan iman jemaat. Orang percaya dari abad ke abad, maka tidak dapat disangkali telah terjadi banyak tantangan. Paulus menulis kepada jemaat Kolose oleh sebab guru-guru palsu telah menyusup ke dalam gereja. Mereka mengajar bahwa penyerahan kepada Kristus dan ketaatan kepada ajaran para rasul tidak memadai untuk mendapat keselamatan penuh. Para pengajar sesat ini mencampur filsafat dan tradisi manusia dengan Injil (Kol. 2: 8). Mereka meminta penyembahan para malaikat sebagai pengantara Allah dan manusia (Kol. 2:18). Para guru palsu ini menuntut pelaksanaan beberapa syarat agama Yahudi $(2: 16,21$ - 23) serta membenarkan kekeliruan mereka dengan menyatakan bahwa mereka mendapat wahyu melalui penglihatan-penglihatan (2:18). Paulus membuktikan salahnya bidat ini dengan menunjukkan bahwa Kristus bukan saja Juruselamat pribadi orang percaya, tetapi kepala gereja dan Tuhan semesta alam dan pencipta. Karena itu, bukannya filsafat atau hikmat manusia yang diunggulkan, melainkan Yesus Kristus dan Kusa-Nya di dalam kehidupan orang percaya itulah yang menebus dan menyelamatkan orang percaya untuk selama-lamanya, perantara tidak perlu dan kita sebagai orang percaya langsung dapat menghampiri Allah. Orang percaya hanya beriman kepada Kristus saja, bersandar kepada-Nya, mengasihi-Nya dan hidup di hadirat-Nya. Kita sebagai orang percaya tidak boleh menambah aturanaturan yang bertentangan dengan Injil Kristus.
\end{abstract}

Kata-kata Kunci: Keunggulan Kritus, Kepala Gereja, Kolose, Gereja

\begin{abstract}
God's church as always been facing obstacles and trials throughout history, the church has been challenged in many ways, whether it is from inside or outside, to bring the people's faith to failure for centuries. Therefore, it cannot be ignored that there have been challenges in a large number. Paul wrote to the church at Colossae to respond to the false teachers that had been slipped into the church. They teach that surrendering to Christ and obedience to the apostles teaching is not sufficient to grant full salvation. These false teachers mixed philosophy and human tradition with the Gospel (Col. 2:8). And asked for the worship of the angels as the mediator between God and men (Col. 2:18). These false teachers demanded certain Jewish practices (Col. 2:16, 21-23) and also justified their fallacies by stating that they had the revelation through visions (2:18). Paul has proven the false teachers' faults by showing that Christ is not only believers' personal savior, but also the head of the church and the Lord, and the Creator. Therefore, it is neither the philosophy nor human wisdom that must be seeded, but Jesus Christ and His Power within a believer's life that has redeemed and saved believers forever, we need no mediator and we as believers can approach God directly. Believers need only to have faith in Christ, rely on Him, love Him, and live in His presence. We, as believers, may not add rules that are not according to the Gospel.
\end{abstract}

Keywords: Christ Superiority, Head of Church, Colossians, Church 


\section{Pendahuluan}

Alasan Paulus untuk menulis surat ini adalah munculnya ajaran palsu yang mengancam masa depan rohani jemaat Kolose (Kol. 2:8). Maksud Paulus ini adalah untuk memberikan penguatan kepada jemaat, supaya orang Kristen di Kolose tidak mudah tergoda oleh ajaran-ajaran yang menyesatkan. Paulus menghendaki supaya ajaran yang telah jemaat terima yakni Injil tentang Yesus Kristus adalah Injil yang benar. Ketika Epafras, seorang pemimpin dalam gereja Kolose dan sebagai pendiri jemat ini, mengadakan perjalanan untuk mengunjungi Paulus dan memberitahukan tentang situasi di Kolose (Kol $1: 8 ; 4: 12$ ), Paulus menanggapinya dengan menulis surat ini. Pada waktu itu ia berada dalam tahanan (Kol. 4:3, 10, 18), mungkin sekali di Roma (Kis 28:16-31) sambil menantikan naik bandingnya kepada Kaisar (Kis 25:11,12). Rekan Paulus yaitu Tikhikus sendiri membawa surat ini ke Kolose atas nama Paulus (Kol. 4:7).

Sifat yang tepat dari ajaran palsu yang terdapat di Kolose ini tidak diuraikan dengan jelas dalam surat ini, kemungkinan besar karena para pembaca yang mula-mula sudah memahaminya dengan baik. Akan tetapi dari berbagai pernyataan Paulus yang menentang ajaran palsu itu, nyatalah bahwa bidat yang hendak meruntuhkan dan menggantikan Yesus Kristus sebagai inti kepercayaan Kristen adalah suatu campuran yang aneh yang terdiri atas ajaran Kristen, tradisi-tradisi Yahudi tertentu di luar Alkitab dan filsafat kafir (serupa dengan campuran kultus-kultus dewasa ini). Pentingnya pembahasan ini mendapat perhatian yang khusus oleh orang percaya, karena hal ajaran sesat itu bukan saja salah tetapi akan sangat berbahaya dalam pertumbuhan iman orang percaya.

Sebagai orang percaya yang berpegang kepada kebenaran Alkitab adalah firman Allah tanpa salah. Alkitab adalah penuntun setiap umat Tuhan ke dalam ajaran yang benar, Alkitab sebagai filter untuk setiap pengajaran orang percaya.

Alasan Rasul Paulus menulis surat ini adalah munculnya ajaran palsu yang mengancam iman serta kehidupan rohani jemaat Tuhan di Kolose
(Kol. 2:8). Ketika Epafras, seorang pemimpin dalam gereja Kolose, mengadakan perjalanan untuk mengunjungi Paulus dan memberitahukan tentang situasi di Kolose (Kol. 1:8; Kol. 4:12). Ajaran sesat yang ada di jemaat Kolose sangat memengaruhi iman jemaat ini, sebab itu Paulus menulis surat kepada jemaat di Kolose dengan tujuan untuk memurnikan kembali pemahaman jemaat terhadap karya Kristus bahwa Kristus adalah Allah yang Mahakuasa dan Ia lebih utama dari segala sesuatu yang telah diadakan-Nya (1:15). Hal Ini menjadi perhatian Paulus sebab ajaran palsu di Kolose sedang berusaha menggantikan keunggulan Kristus dan kedudukan-Nya sebagai inti dalam ciptaan, penyataan, penebusan dan gereja.

Komentar Henry H. Halley sehubungan dengan sumber permasalahan jemaat Kolose yakni,

\footnotetext{
Kericuhan bidat di Kolose, agaknya merupakan campuran agama-agama Yunani, Yahudi dan timur, dan merupakan semacam ibadat "hikmat tinggi" yang membanggakan diri sebagai "filsafat" (2:8) dan menyembah malaikat yang dianggapnya sebagai pengantara antara Allah dengan manusia (2:18), dan melaksanakan beberapa tuntutan yang tertentu dari agama Yahudi sehingga mendekati semacam ajaran kaum pertapa (asketisme 2:16, 21), dan menonjolkan keunggulan; dan kesemuanya ini dianggapnya selaku bagian Injil Kristus. ${ }^{1}$
}

Jelas hal ini sangat melemahkan kemahakuasaan Yesus Kristus, sebab yang lebih penting di sini adalah penyembahan kepada malaikat-malaikat. Hal ini sungguh menyesatkan karena tidak sesuai dengan kebenaran yang telah diterima oleh jemaat yang ada di Kolose.

Kepentingan utama dari tanggungjawab Paulus adalah meyakinkan orang-orang Kristen di Kolose tentang keilahian Yesus Kristus. Yesus Kristus adalah Tuhan, Dialah yang patut disembah dan Dialah yang lebih utama dari segala sesuatu, dan segala sesuatu ada dibawah tangan kuasa-Nya.

Pembahasan tentang keunggulan Yesus Kristus dalam bagian ini adalah bersumber dari tiga ayat teks Alkitab Kolose 1:16-18.

${ }^{1}$ Henry H. Halley. Penuntun Ke dalam Perjanjian Baru. (Surabaya: Yakin, 1979), 240. 
Karena di dalam Dialah telah diciptakan segala sesuatu, yang ada di sorga dan yang ada dibumi, yang kelihatan dan yang tidak kelihatan, baik singgasana, maupun kerajaan, baik pemerintah, maupun penguasa; segala sesuatu diciptakan oleh Dia dan untuk Dia. Ia ada terlebih dahulu dari segala sesuatu dan segala sesuatu ada di dalam Dia. Ialah kepala tubuh, yaitu jemaat. Ialah yang sulung, yang pertama bangkit dari antara orang mati, sehingga Ia yang lebih utama dalam segala sesuatu. ${ }^{2}$

Berdasarkan teks ini, ada empat pokok tentang Keunggulan Yesus Kristus yakni: Yesus Kristus adalah pencipta, Yesus Kristus adalah kekal, Yesus Kristus adalah kepala tubuh dan Yesus Kristus adalah yang pertama bangkit dari antara orang mati.

\section{Yesus Kristus Adalah Pencipta}

Berbicara mengenai proses penciptaan Alam semesta dan segala isi nya ini, tidak dapat dilepaskan dari tiga pribadi Allah yang Esa. Dalam proses penciptaan, ketiga pribadi ini yakni: Bapa, Anak dan Roh Kudus terlibat secara aktif dalam ciptaan (Kej. 1). Dalam teks pembahasan ini menjelaskan Kristus menunjukkan peran-Nya sebagai pribadi yang ikut serta dalam penciptaan.

Karena di dalam Dialah telah diciptakan segala sesuatu, yang ada di sorga dan yang ada dibumi, yang kelihatan dan yang tidak kelihatan, baik singgasana, maupun kerajaan, baik pemerintah, maupun penguasa; segala sesuatu diciptakan oleh Dia dan untuk Dia (Kolose 1:16).

Dalam ayat ini jelas bahwa Kristus adalah pencipta dan suatu pernyataan yang luas mengenai peranan Kristus dalam penciptaan. Paulus menempatkan Kristus sebagai pribadi yang terlibat langsung dalam penciptaan dunia dan segala isinya. Memperlihatkan luasnya pekerjaan Kristus dan menyatakan bahwa suatupun tidak ada di dunia ini yang tidak ada hubungan dengan Kristus. Tidak ada sesuatu pun di bawah langit, yang berada di luar kekuasaan-Nya. Di dunia ini boleh ada makhlukmakhluk yang baik dan jahat, boleh ada roh-roh yang baik dan jahat, tetapi semuanya itu

${ }^{2}$ Kolose 1:16-18. tergantung dan takluk kepada Yesus Kristus. Dialah tuan dan Tuhannya, oleh karena Dialah pengantara kejadian dan pengantara penebusan.

Dalam teks Kolose 1:16 ini, sepertinya Paulus sedang menyinggung kegelisahan yang dialami oleh jemaat Kolose dan mempertegas kembali pengertian jemaat tentang kebenaran yang ada dalam Tuhan Yesus Kristus. Bolkestein juga mengomentari bagian ini, ia mengatakan;

Di Kolose ada orang berpikir, bahwa Kristus hanyalah penebus jiwa, bukan Tuhan yang melingkupi segala sesuatu. Di samping Kristus masih ada roh-roh yang harus ditakuti. Kristus betul Tuhan yang besar kuasa-Nya, tetapi Tuhan bukan yang maha Esa. Banyak perkara di bawah kekuasaan Kristus, tetapi bukan seluruh dunia. Di luar Kristus masih ada kuasa-kuasa yang bergerak dengan bebas dan yang dapat membahayakan hidup manusia, demikian pikiran mereka. ${ }^{3}$

Inilah pokok pikiran para penyesat yang ada di Kolose, Pernyataan mereka sangat meremehkan kemahakuasaan Kristus sebagai pencipta dan melemahkan karya Kristus dalam penebusan. Oleh sebab itu rasul Paulus dalam ayat ini, mengadakan pembelaan dan meniadakan dasardasar pendapat para penyesat karena ajaran mereka salah dan sangat bertentangan dengan kebenaran firman Tuhan. Rasul Paulus menempatkan Kristus sebagai pusat dari penciptaan dan menegaskan keunggulannya. ${ }^{4}$

Ajaran sesat yang memengaruhi iman Kristen di Kolose, tidak mengakui Yesus Kristus sebagai Tuhan yang Esa. Dalam hal ini, para pengajar sesat sangat memengaruhi ajaran tentang hakikat ketritunggalan Allah. Jelaslah bahwa pekerjaan penciptaan akan terlepas dari pribadi kedua dari Allah Tritunggal yaitu Tuhan Yesus Kristus. Benar ajaran ini adalah salah dan bertentangan dengan ajaran Alkitab. Sebagaimana telah diawali dalam pokok pembahasan di atas, bahwa benar proses penciptaan itu adalah tidak terlepas dari cara kerja ke tiga oknum Allah Tritunggal. J. Wesley Brill menulis yakni, "Allah yang menjadikan, tetapi Ia bekerja juga melalui Anak

${ }^{3}$ M.H. Bolkestein. Tafsiran Kolose. (Jakarta: BPK Gunung Mulia,1966), 41.

${ }^{4}$ Donald Gutrie. Teologi Perjanjian Baru 1. (Jakarta: BPK Gunung Mulia,1992), 48. 
dan Roh Kudus. Jadi, tepatnya pekerjaan penciptaan dilakukan oleh ketiga pribadi yang Esa itu. ${ }^{5}$ Bahwa pekerjaan menjadikan, yang dilaksanakan oleh Bapa, tidak berlaku di luar Anak. Pada mulanya Anak mempunyai bagian di dalam menjadikan. Pada mulanya juga dunia ini adalah milik Yesus Kristus. ${ }^{6}$ Adalah benar duni ini milik Yesus Kristus sehingga orang percaya tidak perlu takut dengan segala seuatu roh-roh jahat yang ada di bumi, sebab segala sesuatu telah ditaklukan di bawah Kristus (1 Korintus 15:28).

Keikutsertaan Yesus Kristus dalam proses penciptaan adalah suatu bukti yang akurat bahwa Ia adalah Allah yang Maha Kuasa, serta menunjukkan keutamaan-Nya dari segala sesuatu yangtelah diadakan-Nya.

Hal di atas lebih dipertegas lagi oleh rasul Yohanes. Yohanes mencatat, segala sesuatu dijadikan oleh Dia dan tanpa Dia tidak ada suatupun yang telah jadi dari segala yang dijadikan (Yohanes 1:3). Ungkapan ini adalah membuktikan bahwa Yesus Kristus adalah pencipta dunia.

Keterlibatan Yesus Kristus dalam proses penciptaan adalah salah satu bukit bahwa Ia adalah yang berkuasa. Jelaslah juga bahwa ke Allahan itu dimiliki Kristus, dapat terlihat dalam karya-Nya terhadap terciptanya alam semesta ini, oleh sebab itu Ia layak dihormati, dipuji, disembah dan diimani.

Dalam Kolose 1:15-20, adalah sumber ditulisnya pembahasan ini, sebagaimana rasul Paulus mengungkapkan tentang keutamaan Kristus, dan tersirat dalam surat ini adalah keilahian Kristus. Layaklah Ia punya gelar dan kehormatan, gelar kehormatan yang dipakai bagi Kristus adalah,

Gambar Allah yang tidak kelihatan, "yang sulung” lebih utama dari segala yang diciptakan, "didalam Dialah roh telah diciptakan segala sesuatu, "segala sesuatu ada di dalam Dia”, kepala jemaat, "Ialah yang sulung, yang pertama bangkit dari antara orang mati, seluruh kepenuhan Allah berkenan diam didalam Dia, oleh Dialah Ia memperdamaikan segala sesuatu. Kristus ada

${ }^{5}$ J. Wesley Brill. Dasar yang Teguh. (Bandung: Kalam Hidup, tt), 66.

${ }^{6}$ Guthrie, 404. ditengah-tengah kamu, Kristus yang adalah pengharapan akan kemuliaan (1:27). Di dalam Dialah tersembunyi segala harta hikmat dan pengetahuan (2:3). Dalam Dialah berdiam secara jasmaniah seluruh kepenuhan ke Allahan (2:9). Kamu telah dipenuhi di dalam Dia (2:10). Kepala semua pemerintah dan penguasa, yang sulung lebih utama dari segala yang diciptakan (ayat 15). ${ }^{7}$

Untuk dapat mengerti ayat 15 ini, bukan berarti Yesus Kristus diciptakan, melainkan arti Perjanjian Lama, yaitu bahwa Ia adalah "ahli waris" semesta yang diciptakan. ${ }^{8}$

Keterlibatan Yesus Kristus dalam proses penciptaan juga dibahas dalam kitab Perjanjian Lama, secara khusus dalam kitab kejadian. Dalam buku tafsiran kitab kejadian jilid 1, dalam hal ini penulis buku ini mengeksposisi ayat-ayat dalam kejadian 1:2, yakni,

Dalam pasal 1 ayat 2 di antara lain kita membaca ....maka Roh Allah melayang-layang di atas permukaan air. Dan dalam ayat 3, kita baca...maka firman Allah hendaklah ada terang. Berhubungan dengan itu, maka dengan tegas kami dapat menunjukkan "kesatuan" Allah dalam tiga zat atau oknum yaitu yang disebut terang, ialah Allah putera sebagaimana Tuhan Yesus mengumpamakan diriNya:.......Aku inilah terang dunia, sedang yang disebut Roh yang melayang-layang itu yaitu Allah Roh Suci. ${ }^{9}$

Dalam ayat 26 ada tertulis dengan jelas katakata ini, "Baiklah Kita menjadikan...." dan "......atas teladan kita" maka pengertian kata "kita" itu menyatakan bahwa yang berkata-kata itu lebih dari satu keadaannya. ${ }^{10}$ Dalam bahasa Ibrani, pasal 1 ayat 1 kitab Kejadian, menggunakan kata, Eli atau Eloi (artinya Allah atau Tuhan), maka dijadikan oleh Eli atau Eloi akan langit dan bumi, sedangkan dalam arti kata "Eli atau Eloi" itu, menerangkan keadaan yang lebih dari bilangan satu. ${ }^{11}$

Melihat dari beberapa keterangan yang telah diutarakan di atas bahwa, dapatlah dikatakan kesatuan dari ketiga pribadi itu tidak dapat

\footnotetext{
${ }^{7}$ Halley, 241.

${ }^{8} \mathrm{Ibid}$.

${ }^{9}$ R.A. Jaffray. Tafsiran Kitab Kejadian Jilid 1.

(Bandung: Kalam Hidup, 1966), 16.

${ }^{10}$ Ibid.

${ }^{11}$ Ibid.
} 
dipisah-pisahkan dan tetap satu dalam karya-Nya, sifat-Nya dan kehendak-Nya. Istilah menciptakan menurut Henry C. Thiessen yakni:

Istilah "menciptakan" dipakai dalam dua arti di dalam Alkitab, dalam arti penciptaan langsung dan dalam arti penciptaan tidak langsung. Penciptaan langsung merupakan tindakan bebas Allah Tritunggal. Melalui tindakan ini Allah pada mulanya menciptakan segala sesuatu yang nampak dan yang tidak nampak untuk kemuliaan-Nya sendiri tanpa memakai bahan yang sudah ada sebelum dunia diciptakan atau tanpa sebab-sebab sekunder. Jadi, ketiga sama-sama mengambil bagian dalam tindakan penciptaan langsung ini. ${ }^{12}$

Dengan melihat beberapa sumber dari keterangan di atas, maka hal ini adalah merupakan bukti-bukti yang otentik bahwa Yesus Kristus adalah pelaku dari penciptaan.

Dalam teks 1 Korintus 8:6 dan Ibrani 1:2; 2:10; 11:3, juga dijelaskan bahwa Yesus Kristus pribadi kedua dari Allah Tritunggal itu turut aktif dalam proses penciptaan. Keterlibatan Yesus Kristus dalam penciptaan juga sebagai bukti bahwa Ia adalah Mahakuasa dan punya kekuasaan yang penuh, yang juga semua ciptaan takluk di bawah kuasa-Nya. Yesus Kristus berkuasa atas segala sesuatu yang telah dijadikanNya. Sebab itulah Yesus Kristus adalah lebih utama dalam seluruh aspek kehidupan manusia, unggul dalam segala sesuatu, Dialah yang patut dipuji dan disembah dan pribadi yang patut ditaati dan diimani.

Paulus dalam teks pasal 1:16 ini menyatakan hal yang prinsip mengenai karya Kristus dalam penciptaan. Dengan jelas Paulus dalam ayat ini, menempatkan Kristus di atas semua ciptaan. Kristus pribadi kedua dari Allah Tritunggal turut serta dalam penciptaan alam semesta ini.

Pokok pengajaran Paulus tentang penciptaan adalah teologia Paulus yang kuat dalam melawan ajaran sesat di Kolose. Paulus mengangkat teologianya terhadap Kristus sebagi pribadi kedua yang terlibat langsung dalam penciptaan. Maka Paulus dengan tegas menyatakan kepada jemaat Tuhan di Kolose bahwa Kristuslah dasar segala sesuatu yang ada dan Kristus lebih utama dalam kehidupan jemaat.

Sebagai orang Kristen harus sadar bahwa maksud dari penciptaan itu hanya untuk kemuliaan-Nya sendiri. Jadi, segala sesautu yang telah diadakan-Nya dapat memuliakan Dia. Kemuliaan dan hormat hanyalah dapat disampaikan kepada Kristus. Alkitab menyatakan, "Ya Tuhan kami, betapa mulianya namaMu di seluruh bumi, keagungan-Mu yang mengatasi langit (Mazmur 8:2) langit menceritakan kemuliaan Allah (Mazmur 19:2) dan "maka kemuliaan Allah akan dinyatakan dan seluruh umat manusia akan melihatnya bersama-sama (Yesaya 40:5).

\section{Yesus Kristus Adalah Kekal}

Didalam ayat 17 "Ia ada terlebih dahulu dari segala sesuatu dan segala sesuatu ada di dalam Dia” nampaknya Paulus dalam hal ini mengulangi lagi apa yang telah dikatakannya, Yesus Kristus adalah terdahulu daripada sekaliannya, tetapi kemudian ia menambahkan suatu pikiran yang baru.

Di dalam ayat 16 ia telah mengatakan bahwa segala sesuatu kejadian berasal dari Kristus, tetapi sekarang ia berkata lagi bahwa sampai sekarang semuanya, wujudnya ada didalam Dia. Bukan hanya sekali, tetapi senantiasa Yesus Kristuslah yang memikul dunia ini dan oleh Dia, dunia ini masih dipelihara. Bentuk kata kerja dalam bahasa Yunani yang digunakan Paulus menunjukkan bahwa di dalam ayat 16 menoleh ke zaman masa lampau, sedang di dalam ayat 17 Ia melihat suatu pekerjaan yang masih berlangsung terus. Sesaatpun kuasa-kuasa setan itu tiada terlepas dari genggaman-Nya. Ia adalah Alfa dan Omega, ........yang ada dan yang sudah ada dan yang akan datang, yang Mahakuasa (Wahyu 1:8; 21:6; 22:13). ${ }^{13}$ Alfa dan Omega adalah huruf pertama dan terakhir dalam abjad Yunani. Jadi, Kristus adalah menguasai segala sesuatu, dari awal sampai akhir, Ia tidak ada tandingannya.

${ }^{13}$ Dorren Widjana, Kupasan Firman Allah surat Kolose (Bandung: Lembaga Literatur Baptis, 1994), 39-40. 
Kekekalan Kristus tidak hanya berarti bahwa Kristus sudah ada sebelum kelahiran-Nya atau bahkan sebelum penciptaan, tetapi ia telah ada dari masa kekekalan (dari selama-lamanya) tidak berawal dan tidak berakhir, terus menerus ada.

Biasanya kekekalan Kristus dan praeksistensinya berdiri sama-sama. Praeksistensi Kristus berarti ia telah ada sebelum dilahirkan, bagi orang percaya hal ini berarti bahwa Ia telah ada sebelum penciptaan dan sebelum ada waktu. Akan tetapi, dalam arti yang sempit praeksistensi tidaklah sama dengan kekekalan. Salah satu contoh adalah Arius, ia mengajarkan prakeksistensi, tetapi ia tidak mengajarkan kekekalannya. Ia tidak percaya bahwa Kristus adalah kekal. ${ }^{14}$ Ia berpegang bahwa Kristus adalah roh pertama yang diciptakan. Pendapat ini salah dan layak ditolak dan selayaknya pendapat ini mendapat sanggahan yang cukup kuat dari kaum Injili. Itulah sebabnya doktrin kekekalan Kristus penting sekali untuk dipahami dengan benar.

\section{Pentingnya Kekekalan}

Berhubungan dengan ketritunggalan Allah, jika kekekalan Kristus ditolak, maka tidak ada pengakuan tentang tritunggal Allah. Ketiga oknum ini sama hakekat, sifat dan kemuliaan. Berhubungan dengan keAllahan-Nya, kekekalan dari pada Kristus harus ada, karena hal ini adalah pernyataan kebenaran bahwa Kristus adalah Allah. Satu pribadi hanya dapat disebut Allah jika memiliki sifat kekal. Berhubungan dengan pernyataan-Nya, jika Kristus tidak kekal, berarti Ia adalah seorang pembohong. Pernyataan Kristus dibuktikan dengan ayat-ayat seperti berikut, Yohanes 8:58. Kata Yesus kepada mereka: "Aku berkata kepadamu, seseungguhnya sebelum Abraham jadi, Aku ada. Yohanes 1:1 Pada mulanya adalah Firman, Firman itu bersama-sama dengan Allah dan Firman itu adalah Allah. Kristus dalam kekekalannya adalah menyatakan bahwa Kristus adalah Allah dan hal ini juga menunjukkan keunggulan-Nya dari segala sesuatu yang telah diadakan-Nya.

\footnotetext{
${ }^{14}$ Walvoord, 15.
}

\section{Bukti Kekekalan Kristus}

Bukti dari Perjanjian Lama, "bukti-bukti dalam Perjanjian Lama tentang kekekalan Kristus bersifat langsung dan juga tidak langsung. ${ }^{15}$ Dalam nubuatan mengenai Kristus (Mesias) dikatakan bahwa Anak itu akan dilahirkan di Betlehem yang permulaannya sudah sejak purbakala sejak dahulu kala (Mikha 5:1). Ini adalah salah satu di antara banyak bagian lain yang berbicara tentang kekekalanNya. Ayat ini adalah nubuatan tentang kelahiran Mesias di Betlehem, namun ditekankan bahwa bayi itu permulaannya sudah sejak dahulu kala. Ungkapan dalam ayat ini mengandung pengertian "waktu yang tak terbatas." ${ }^{16}$ Seperti yang dikatakan John F. Walvoord, yakni: "istilah-istilah ini memberikan pernyataan yang terkuat tentang Kristus yang dapat dilukiskan oleh bahasa Ibrani (bandingkan Mazmur 90:2; Amsal 8:22-23; Yohanes 1:1)."17 Keil, dalam suatu diskusi penjang lebar mempertahankan konsep tentang kekekalan atau keilahian Anak yang dijanjikan itu ia berkata, yang dikutip oleh John F. Walvoord yakni:

\section{Pengumuman tentang asal mula pemimpin ini, yang dikatakan telah ada sebelum dunia dijadikan, tidak perlu diragukan lagi menunjuk kepada sifat keilahian-Nya, tetapi pikiran ini tidak aneh pada nubuatan di zaman Mikha dan dinyatakan dengan tegas oleh Yesaya ketika ia memberikan gelar, Allah yang perkasa, kepada Kristus. ${ }^{18}$}

Semua nubuatan Perjanjian Lama tentang kedatangan Kristus yang menyatakan keilahianNya adalah juga merupakan bukti bagi kekekalan-Nya. Dalam diktat mata kuliah Kristologi materi pembahasan tentang kekekalan Kristus, Yesaya 9:5 adalah sebagai topik pembahasan, yang dinyatakan dalamayat ini merupakan nubuatan yang sangat luar biasa tentang inkarnasi Kristus, sebagai berikut:

Ajaib dalam bahasa inggrisnya "Wonder" berasal dari istilah "Phele" dalam bahasa asli yang memberi

\footnotetext{
${ }^{15} \mathrm{Ibid}, 16$.

${ }^{16}$ Ibid.

${ }^{17}$ Ibid.

${ }^{18}$ Ibid.
} 
arti suatu rahasia besar. Memang dalam diri Kristus sendiri sulit untuk dipahami oleh intelektual manusia yang mempunyai daya pikir yang terbatas. Penasehat dalam bahasa inggrisnya "Counselor" dari kata "Yoetz" berarti seseorang yang memiliki hikmat dan kemampuan ilahi untuk menilai dan menopang, serta mampu menembusi peristiwaperistiwa yang ada sehingga dapat melihat kehendak Allah dan penerpannya. Ayat-ayat Alkitab Yesaya 11:2; Kolose 2:3; 1 Kor 1:30. Allah yang perkasa, dalam bahasa inggrisnya "mighty God" berasal dari kata "ELGIBOR” ELOHIM, ini menunjuk kepada hakekat pribadi-Nya. Bahwa sesungguhnya Allah mempunyai kemampuan yang sungguh tidak ada tandingannya. Bapa yang kekal, (Everlasting father), istilah Ibraninya "ABI AD" (sumber kekal/pemilik kekal), seharusnya lebih tepat dikatakan Bapa, pemilik kekekalan. Namun yang dibicarakan di sini adalah Mesias yang akan datang yaitu pribadi kedua Tritunggal, Ia menguasai zaman daripadanya waktu menjadi kenyataan. Raja damai, (Prince of peace), dalam bahasa Ibraninya "SARSHALOM" istilah ini dipakai juga dalam Zakharia 9:10; Kolose 1:20; Efesus 2:14. Hal ini menyatakan bahwa Mesias yang akan datang itu adalah Raja damai. ${ }^{19}$

Hal-hal di atas menjelaskan tentang nubuatan kedatangan-Nya, namun didalamnya terkandung pengertian kekekalan dari Mesias yang akan datang itu. Hal ini nampak jelas dalam Perjanjian Baru.

Kekekalan Kristus sering dinyatakan juga dalam Perjanjian Baru dengan istilah-istilah yang lebih tegas dari Perjanjian Lama. Pendahuluan dalam Injil Yohanes biasanya dianggap peneguhan tentang kekekalan Kristus. John F. Walvoord menyatakan,

Pada mulanya adalah Firman...dan Firman itu adalah Allah (Yoh 1:1). Perkataan pada "mulanya" (Yunani en archei) agaknya menunjuk kepada suatu waktu dalam masa kekekalan yang silam yang mustahil kita datangi, seperti yang ditafsirkan oleh I. A. Doner. Kata kerja yang dipakai dipilih untuk menyatakan kekekalan, karena kata "adalah" (Yunani, en) berarti keberadaan yang terus menerus. Marcus Dods mengatakan, Firman itu bukannya mulai ada pada mulanya, melainkan pada titik dimana semua yang lain mulai ada, Ia telah ada. $^{20}$

\footnotetext{
${ }^{19}$ Deimy F. Tendean. Diktat Kristologi. (Pontianak: STT Kalimantan, Semester VI, 1993).

${ }^{20}$ Walvoord, 17
}

Jadi jelas bahwa Kristus ada sebelum dunia dijadikan, dan Ia telah ada pada kekekalan masa lampau dan Ia terus menerus ada dari dahulu kala sampai pada masa kini dan yang akan datang.

Dalam Yohanes 8:58, ayat ini merupakan puncak dari suatu seri pernyataan Yesus Kristus perihal dimulai dari Yohanes 8:12. Ada perulangan "Akulah-Aku ada", pemakaian kata ini selain menyatakan bahwa Yesus Kristus selalu ada dan tidak pernah tidak ada (kekal), Ia juga menunjukkan hubungan Yesus Kristus dengan Allah Perjanjian Lama atau Yahweh (Keluaran 3:14).

Dalam Perjanjian Baru seperti juga yang terdapat dalam Perjanjian Lama ada banyak argumentasi yang mendukung pernyataan tentang keilahian dan kekekalan Kristus seperti gelar-gelar-Nya, pekerjaan-Nya, sifat-sifat ilahiNya, janji-janji-Nya yang kekal dan hampir segala aspek pribadi dan pekerjaan-Nya menyatakan keilahian-Nya. Apabila Kristus sungguh-sungguh Allah, Ia juga sungguh-sungguh kekal, dalam sejarah gereja penting diperhatikan bahwa penyangkalan terhadap kekekalan Kristus berarti pula penyangkalan terhadap kitab suci sebagai Firman Allah, dan ini merendahkan pribadi Kristus menjadi lebih rendah daripada Allah sendiri. Dalam kepercayaan yang mula-mula belum pernah ada penyangkalan yang berhasil terhadap kekekalan Kristus, dan dasar keyakinan kepercayaan yang pertama sepanjang sejarah gereja adalah menyatakan dengan tegas kekekalan Kristus.

\section{Yesus Kristus Ada Lebih Dahulu (Pra Eksistensi)}

Meskipun ungkapan yang menyatakan Kristus telah ada terlebih dahulu, yaitu telah ada sebelum kelahiran-Nya di Betlehem, nampakya tidak persis sama dengan yang mengatakan bahwa Ia kekal, namun secara jelas bukti tentang pra eksistensinya lebih diterima oleh para ahli teologia sebagai bukti kekekalan-Nya. Sejak perselisihan dari kelompok Arian pada abad keempat, belum pernah orang menyangkal pra eksistensi-Nya. Bukti bahwa Kristus sudah ada 
dalam Perjanjian Lama adalah mendukung bukti tentang kekekalan-Nya.

Doktrin bahwa Kristus sudah ada sejak kekekalan masa lampu telah menjadi teologi ortodoks dari gereja, yang dengan jelas diumumkan sejak Dewan Nicea diadakan. Kekekalan Kristus tidak hanya penting bagi keilahian oknum Allah kedua ini, tetapi juga merupakan dasar dalam doktrin Tritunggal.

Ajaran tentang kekekalan Kristus adalah doktrin yang penting bagi Paulus dalam hal iman Paulus kepada Kristus, tetapi juga dalam hal ini untuk melawan ajaran sesat yang ada di Kolose. Kata yang dipakai Paulus dalam ayat 17, adalah menujuk kepada keberadaan Kristus dimasa lampau. Paulus merasa bahwa ajaran sesat itu dapat merusak iman jemaat. Oleh sebab itu Paulus mengingatkan jemaat Kolose bahwa segala sesuatu dari kejadian adalah berasal dari Kristus dan sampai selama-lamanya Kristus tetap ada dan Ia terus menerus ada dari dahulu, saat ini sampai kepada masa yang akan datang. Ia terus berkuasa dan oleh Dia dunia ini dipelihara.

Kristus adalah yang menguasai segala sesuatu yang ada di bumi ini. Dari awal sampai akhir Kristus berkuasa, tidak ada kuasa lain atau rohroh jahat yang dapat mengalahkan kuasa Kristus. Oleh sebab itu orang percaya tidak perlu takut terhadap roh-roh jahat di dunia. Karena Kristus adalah yang kekal, yang olehnya segala sesuatu yang ada di dunia ini telah dijadikan layaklah Ia dipuji diagungkan dan disembah.

\section{Yesus Kristus adalah Kepala Tubuh}

Yesus Kristus sebagai kepala gereja adalah merupakan konsep yang paling besar bagi Paulus, sebagaimana diungkapkan oleh Yoshua Ong, yakni:

Salah satu konsep Paulus yang besar adalah konsep mengenai gereja sebagai tubuh Kristus dan gambar yang serupa dengan itu adalah gambaran Yesus Kristus sebagai kepala gereja. ${ }^{21}$

\footnotetext{
${ }^{21}$ Chris Marantika, editor. Yesus Kristus Allah, Manusia Sejati, Artikel Yesus Kepala Tubuh. (Surabaya: PASTI dan Yakin, 1983), 104.
}

Ia adalah kepala tubuh itu, yakni gereja (Kolose 1:18). Didalam ayat ini, Paulus menonjolkan betapa pentingnya Kristus dalam gereja. Setiap anggota tubuh tidak mungkin ada dan tak mungkin berfungsi tanpa kepala. Gambaran tubuh berharga pula, karena menekankan kepada kesatuan gereja atau jemaat.

Sebenarnya ajaran sesat yang timbul di Kolose adalah orang-orang yang tidak berpegang teguh kepada-Nya,

Kepala darimana seluruh itu ditunjang dan diikat menjadi satu oleh urat-urat dan sendi-sendi untuk bertumbuh dan menerima pertumbuhan ilahi-Nya (Kolose 2:19). ${ }^{22}$

Memang benar bahwa fungsi Kristus sebagai kepala adalah sangat dominan di dalam menumbuhkembangkan gereja. Jadi, yang memberi pertumbuhan gereja adalah Yesus Kristus. Allah telah menaruh segala sesuatu di bawah kaki Kristus, dan telah menjadikan Dia kepala atas segala sesuatu untuk gereja (Efesus 1:22-23). Orang Kristen harus bertumbuh di dalam segala sesuatu kepada Dia yang menjadi kepala, "kepada Kristus darimana seluruh tubuh tersusun dan diikat menjadi satu oleh pelayanan semua bagiannya, sesuai kadar pekerjaan tiaptiap anggota, menerima pertumbuhannya dan membangun dirinya dalam kasih (Efesus 4:15. 16).

Suami itu adalah menjadi kepala istri seperti Kristus juga menjadi kepala gereja yaitu tubuh (Efesus 5:23). Kepala setiap orang adalah Kristus (1 Korintus 11:3). Dalam setiap bahasa apapun, kepala melambangkan keunggulan, kepemimpinan, kekuasaan, bahkan menjadi inti dari kehidupan itu sendiri.

Dalam kitab Perjanjian Lama di sana dibicarakan mengenai pemimpin-pemipin nasional. Pemimpin-pemimpin itu juga kepalakepala keluarga dari kepala suku, misalnya (Keluaran 6:13; 18:25, Bilangan 1:4; 13:3, Yosua 14:1). Kepala-kepala itu dihubungkan dengan penghulu (Bilangan 1:16; 10:4), dengan tua-tua (Yosua 23:2). Dapatlah dikatakan bahwa kepala adalah simbol kepemimpinan. Kepala adalah sangat penting sehingga seringkali kepala adalah 
berarti keseluruhan dari tubuh itu sendiri. Gereja sebagai anggota tubuh Kristus tidak dapat dipisahkan dengan kepalanya, karena semuanya itu mempunyai hubungan dan kesatuan yang utuh, sebab memang kepala adalah pusat dari kehidupan tubuh, dalam buku Yesus Kristus Allah Manusia Sejati, penulis buku ini mengungkapkan yakni:

Dikepala berpusat kehidupan tubuh. Dengan matalah kita melihat, dengan telinga kita mendengar, dengan hidung mencium/membaui, dan diatas semuanya dengan pikiran dan otak kita berpikir. Dengan demikian Yesus Kristus adalah kehidupan gereja, tanpa Dia gereja mati sebagaimana tubuh tanpa kepala. ${ }^{23}$

Dapat dikatakan Kristus sebagai kepala adalah sentral di dalam kehidupan gereja. Oleh sebab itu, fungsi Kristus dalam pertumbuhan tidak dapat diabaikan. Sebagaimana rasul Paulus menulis, dalam suratnya kepada jemaat di Efesus 1:15-23, Paulus mempunyai satu pikiran yang paling agung, paling berani dan paling menggembirakan yang pernah manusia miliki. Di dalam ayat-ayat ini rasul Paulus menyebut gereja dengan gelarnya yang paling agung: tubuh Kristus. "Kristus adalah kepala gereja, dan gereja adalah tubuh Kristus." 24

Gereja harus mempunyai hubungan dengan Yesus Kristus. Di dalam Kristus semua orang dan semua bangsa dapat bersatu. Tetapi memang sebelum hal itu terjadi, semua orang dan semua bangsa harus mengetahui tentang Yesus Kristus dan harus percaya dan menerima Dia sebagai Tuhan dan Juruselamat secara pribadi. Untuk orang lain bisa mengetahui tentang Kristus, tentang kebenaran-Nya, anugerah-Nya, pengampun-an-Nya, kasih-Nya, dan semua itu harus dibawa kepada orang lain kepada pengenalan akan Yesus Kristus.

Sebagaimana Yesus Kristus adalah alat Allah, yang membawa kesatuan antara manusia dengan Allah, yang dahulu pecah dan tidak ada kesatuan, tentunya hanya melalui Yesus Kristus yang menjadi dasar atau pemersatu itu.

\footnotetext{
${ }^{23}$ Ibid.

${ }^{24}$ Ibid.
}

Kepalalah yang memerintah dan mengatur tubuh. Kepala memerintah gerakan tubuh. Tanpa pikiran, tubuh tidak mempunyai tujuan atau maksud gerakan yang efektif. Pikiran mengontrol dan mengatur naluri dan nafsu tubuh. Begitu juga Yesus harus mengatur dan memerintah gerejanya. Hanya Yesus Kristus yang dapat memberi tujuan dan pimpinan kepada gereja, dan hanya Dia juga yang dapat mengekang gereja dari kebodohan manusia. Seperti apa yang dikatakan Armitage Robinson, yang dikutip oleh Yoshua Ong adalah sebagai berikut: fungsi kepalalah untuk merencanakan keselamatan tubuh, untuk mengamankan dari kemurkaan, dan memberikan kesejahteraan. ${ }^{25}$ Kepala mempunyai hak untuk memerintah harus ditaati. Seperti yang dikatakan oleh J.B. Lightfoot, yang dikutip oleh Yoshua Ong, mengenai kepala dalam hubungannya dengan tubuh, Ong menulis:

Kepala mempunyai ilham, pemerintah, pimpinan, menggabungkan, memelihara. Kepala adalah pendorong utama dari kegiatan tubuh, pusat kesatuan tubuh dan pusat kehidupan itu sendiri. ${ }^{26}$

Apa yang telah diungkapkan di atas adalah benar bahwa kepala membimbing, mengatur, menguasai tubuh, tetapi benar juga bahwa tanpa tubuh kepala tidak berdaya. Kepala dapat berpikir dan merencanakan, tetapi pikiran dan rencananya tidak dapat dilaksanakan tanpa tubuh. Bila tubuh membutuhkan kepala mengaturnya, kepala membutuhkan sebuah tubuh untuk digunakan maksudnya. Namun demikian, juga ada arti yang sebenarnya didalam kalimat. Yesus Kristus tidak berdaya tanpa gerejanya. Sebagai contoh bila Yesus ingin seseorang anak diajar, tidak ada seseorang yang dapat mengajar anak itu, kecuali ada seseorang yang siap untuk menerima tugas itu. Bila Yesus Kristus ingin suatu berita diberitakan kepada suatu bangsa, suatu gereja atau seseorang. Ia harus mendapatkan seseorang untuk menjadi pembawa berita-Nya. Menjadi kemuliaan dan sekaligus tanggungjawab gereja, bahwa ia harus
${ }^{25}$ Ibid.

${ }^{26}$ Ibid. 
menjadi tubuh melalui Yesus Kristus bertindak atas dunia ini.

Jadi Kristus adalah kepala, gereja adalah tubuh. Kepala sendiri saja tidak ada gunanya otak saja tidak ada gunanya. Kepala harus mempunyai tubuh yang dapat diperintah-Nya, otak, pikiran harus mempunyai tubuh melalui mana ia dapat bekerja. Sesungguhnya gereja adalah tangan untuk melakukan pekerjaan Kristus, kaki untuk menyampaikan pesan-Nya, suara untuk mengatakan firman-Nya. Dengan demikian sesungguhnya bahwa Yesus Kristus adalah kepala dari seluruh tubuh yaitu gereja, dan selayaknya gereja menempatkan Yesus Kristus yang terutama dan yang lebih utama dari segala sesuatu yang telah diadakan-Nya dibumi ini. Tidak dapat disangkal bahwa Yesus Kristus adalah kepala dari gereja. Dialah pula yang telah mengadakan segala sesuatunya dan segala sesuatu yang ada takluk di bawah kuasa-Nya, dan gereja adalah tubuh-Nya, dan tidak ada kuasa lain yang perlu ditakuti, selain hanya takut kepada Tuhan Yesus Kristus.

Konsep Paulus tentang Yesus Kristus, adalah kepala dari tubuh (Jemaat), hal ini menggambarkan hubungan Kristus dengan jemaat yang memiliki persekutuan yang istimewa atau hubungan yang khusus. Bahwa jemaat mempunyai hubungan yang kuat sebagai satu kesatuan yang utuh yang tidak dapat dipisahkan dari Kristus, laksana tubuh dengan kepala yang adalah sudah menjadi satu. Hal inilah yang menjadi penekanan Paulus, ia memberi pengertian yang pada akhirnya jemaat dapat menyadari bahwa sesungguhnya jemaat Kolose ada dalam pimpinan dan kuasa Allah.

Dapatlah disadari oleh orang percaya bahwa hubungan Kristus dengan jemaat, adalah merupakan mata rantai yang saling berkaitan yang tak terputuskan, oleh sebab itu dalam setiap gerak langkah kehidupan orang percaya tidak terlepas dari kontrol Allah.

\section{Yesus Kristus adalah yang Pertama Bangkit dari Antara Orang Mati}

Rasul Paulus menyebut Kristus, sebagai yang sulung, dimana dalam hal ini rasul Paulus memberi tekanan yang kuat kepada kebangkitan.
Kebangkitan Kristus dari antara orang mati, adalah mujizat yang besar, yang menjadi tempat gereja berdiri.

Pernyataan Paulus tentang Yesus Kristus sebagai yang sulung bangkit dari antara orang mati adalah merupakan serangan Paulus kepada para penyesat di Kolose. Maksud Paulus bahwa selalu Yesus Kristus menjadi mula dan sumber. Sebagaimana Bolkeistein menuliskan,

Selalu Kristus menjadi mula dan sumber. Kejadian pertama berdasar pada-Nya, yang keduapun demikian. Di dalam kedua-duanya, di dalam kejadian, baik di dalam gereja, Ia tetap Tuhan, Dialah yang pertama, Ia memerintah, baik di dalam kejadian, baik didalam jemaat. Dialah yang mempunyai kuasa. Dimana-mana Dialah yang terutama yang permulaan. Yesus Kristus yang berkuasadi luar jemaat, dan sebaliknya kuasa-Nya di luar jemaat, juga di dalam jemaat. ${ }^{27}$

Keterangan di atas menunjuk kepada Kristus yang adalah dasar dari segala sesuatu yang ada, Dialah sumber-Nya. Tepat hal ini juga menunjuk kepada keunggulan Yesus Kristus. Rasul Paulus menghendaki para penyesat di Kolose harus melihat kepada Kristus sebagai sumber dan pusat dari segala sesuatu. Bahwa Yesus Kristus adalah yang memulai dan menjadi sumber. Yang sulung juga mengandung arti, "yang pertama dari sesuatu urutan" ${ }^{28}$ Karena semua orang akan bangkit juga dari kematian sebagai hasil dari kebangkitan Kristus, sebab kematian Yesus Kristus lain dari yang pernah dialami oleh orangorang yang telah mati di zaman Yesus. Sebagai contoh Lazarus, Lazarus mati dan dibangkitkan oleh Yesus, tetapi kemudian Lazarus mati kembali. Sedangkan Yesus mati tetapi sudah bangkit kembali dan Yesus tidak akan mati kembali, Ia hidup untuk selama-lamanya. Kebangkitan Kristus tidak dilihat dari urutan kebangkitan, tetapi harus dipandang dari kualitas kebangkitan Yesus.

Hal ini juga telah dikatakan di atas bahwa doktrin tentang kebangkitan Kristus adalah hal yang sangat penting sekali, kebangkitan adalah menjadi dasar berdirinya gereja, jadi kebangkitan

\footnotetext{
${ }^{27}$ Bolkestein, 56.

${ }^{28}$ Donald Guthrie, editor. Tafsiran Alkitab Masa
}

Kini 3. (Jakarta: BPK Gunung Mulia, 1983), 668. 
Kristus adalah juga menjadi bahasan dalam pokok ini.

Kebangkitan Kristus merupakan pokok doktrin dalam kekristenan. Seperti yang diungkapkan oleh Henry C. Thiessen bahwa kebangkitan tubuh Kristus sangat penting sudah jelas dari hubungan pokok doktrin ini dengan kekristenan. ${ }^{29}$

Dalam 1 Korintus 15:12-19, Paulus menjelaskan bahwa iman seseorang berdiri atau jatuh bersama dengan kebangkitan tubuh Kristus. Apabila Kristus tidak dibangkitkan, semua pemberitaan Injil itu percuma (ayat 14), iman jemaat Korintus sia-sia, para rasul menjadi palsu (ayat 15), orang percaya di Korintus masih hidup dalam dosa (ayat 17). Sebab itu kebangkitan Kristus bagi orang Kristen adalah hal yang sangat penting sebagai sejarah baru atau membuka lembaran baru dan menjadikan kesaksian setiap dari anak-anak Tuhan sungguhsungguh diterima dan dipercayai.

Kebangkitan Kristus dari antara orang mati dan orang yang pertama bangkit dari kematian menunjukkan bahwa Ia adalah memiliki kemahakuasaan dan kebangkitan-Nya menjadi dasar kepercayaan orang Kristen. KebangkitanNya membuktikan keunggulan-Nya dari segala sesuatu yang ada di dalam dunia ini.

Kebangkitan Kristus menjadi dasar kepercayaan orang Kristen, ini adalah kepercayaan yang tidak dimiliki oleh orang yang di luar orang percaya, sebagai umat Kristen layak berbangga bahwa Yesus Kristus yang menjadi pengantara umat-Nya telah menang dan kemenangan itu telah terbukti dari kebangkitanNya sehingga oleh-Nya semua orang percaya akan memperoleh hidup yang kekal.

Berita kebangkitan Kristus adalah pemberitahuan yang sangat ditekankan oleh para rasul, seperti yang diberitakan oleh rasul Petrus (Kisah Para Rasul 2:24, 32; 3:15; 4:10; 5:30; 10:40). 1 Petrus 1:21 yang diberitakan oleh rasul Paulus (Kis 13:30). 1 Korintus 15 dan Filipi 3:21. Oleh sebab percaya akan berita kebangkitan Kristus maka berdirilah gereja, akan kebangkitan Kristus merupakan pokok iman

\footnotetext{
${ }^{29}$ Thiessen, 369.
}

orang Kristen mula-mula dan sampai pada gereja masa kini.

Setiap hal atau yang dipercayai atau diimani tentunya juga akan mendapat perlawanan dari pihak lain. Sebagaimana iman kepercayaan dari gereja mula-mula mendapat tantangan serangan yang cukup kuat dari pihak lain, namun gereja mula-mula bukan hanya gambaran berita kebangkitan saja tetapi ada satu fakta nyata kuburan Kristus yang kosong, dapatlah dilihat bahwa iman jemaat mula-mula dan isi pemberitahuan para rasul saat itu adalah kebangkitan Kristus serta fakta kebangkitan yang nyata. Walaupun ada tantangan tetapi firman Tuhan tetap diberitakan oleh para rasul saat itu. Tentunya makna atau manfaat kebangkitan Kristus sungguh merupakan hal yang sangat berharga sekali khususnya bagi umat Kristen di seluruh dunia.

Manfaat kebangkitan Kristus bagi orang percaya, memberikan jaminan yang memperkenankan Tuhan (Roma 4:25). Yesus yang telah diserahkan karena pelanggaran kita dan dibangkitkan karena pembenaran kita. Oleh sebab itu ketika Yesus berada dalam kubur belum dapat dikatakan bahwa pekerjaan penebusan-Nya sudah memperkenankan Allah, sehingga ketika Ia bangkit dari antara orang mati, dengan jelas menyatakan bahwa Allah berkenan akan korban penyerahan Kristus bagi orang berdosa.

Kebangkitan Kristus juga merupakan jaminan bahwa Ia sebagai juru syafaat bagi orang percaya dihadapan Allah Bapa. Siapakah yang akan menghukum orang percaya, Kristus Yesus yang telah mati bahkan lebih lagi yang telah bangkit yang juga duduk di sebelah kanan Allah, yang malah menjadi pembela bagi orang percaya. Sebagaimana yang diungkapkan oleh penulis Ibrani:

Kesempurnaan itu Ia sanggup juga menyelamatkan dengan sempurna semua orang yang oleh Dia datang kepada Allah sebab Ia hidup senantiasa untuk menjadi perantara mereka (Ibrani 7:25).

Sebagaimana juga Musa yang dibutuhkan oleh umat Israel bukan hanya dibutuhkan oleh bangsanya untuk menyelamatkan bangsa itu dari 
perbudakan orang Mesir, tetapi terlebih lagi sebagai juru syafaat yang mendoakan umatnya dalam perjalanan ke padang gurun.

Kebangkitan Kristus juga sebagai suatu kuasa dalam kehidupan dan pelayanan orang Kristen. Sebagaimana Paulus menulis;

Betapa hebatnya kuasa-Nya bagi kita yang percaya, sesuai dengan kekuatan kuasa-Nya yang dikerjakanNya didalam Kristus dengan membangkitkan Dia dari antara orang mati dan mendudukan Dia disebelah kanan-Nya di sorga...dan Dia telah diberikan-Nya kepada jemaat sebagai kepala dari segala yang ada (Efesus 1:19-22).

Benar bahwa Kristus adalah Allah yang berkuasa, tidak ada kuasa yang lain untuk dapat mengalahkan kuasa Kristus. Kemahakuasaan Allah juga diperlihatkan kepada umat-Nya. Dalam Perjanjian Lama, Ia adalah Allah yang menyelamatkan umat-Nya Israel dari perbudakan Mesir, sehingga umat-Nya mengenal kemahakuasaan-Nya (Mikha 7:15).

Di dalam Perjanjian Baru melalui kebangkitan Kristus. Ia menyatakan keagunganNya sebagaimana janji Allah (Filipi 3:10). Bukan hanya merupakan jaminan bagi orang Kristen tentang kuasa yang akan dimiliki untuk hidup berkemenangan pada masa kini. Juga merupakan jaminan kemuliaan pada masa yang akan datang.

Kebangkitan Kristus juga mempunyai arti yang cukup penting di dalam kehidupan orang percaya, karena kebangkitan Kristus itu sendiri sebagai jaminan kebangkitan dan hidup yang kekal bagi orang yang menjadi milik-Nya. Paulus menyatakan,

Karena jikalau percaya bahwa Yesus telah mati dan telah bangkit, maka kita percaya juga bahwa mereka yang telah meninggal dalam Yesus akan dikumpulkan Allah bersama-sama dengan Dia (1 Tesalonika 4:14)

Dari keterangan diatas menyatakan bahwa setiap orang percaya yang telah meninggal akan bersama-sama dengan Allah asalkan ia sudah menerima Yesus sebagai Tuhan dan Juruselamatnya secara pribadi. Kristus adalah Allah dan Ia berkuasa, kebangkitan Kristus adalah mujizat yang luar biasa yang tidak pernah dialami manusia, Kristus bangkit dan hidup kembali untuk selama-lamanya.

Dengan demikian bahwa Yesus Kristus tidaklah lebih kurang dari segala yang ada, dan Ia sendiri berkuasa atas segala sesuatu dan segala sesuatu ada di dalam Dia. Yesus Kristus lebih utama dari segala yang telah diadakan-Nya.

Konsep Paulus tentang kebangkitan Kristus sebagai Allah yang sulung, Paulus memandang kepada Kristus sebagai Allah yang berkuasa, dengan bangkitnya Kristus maka orang-orang percaya yang ada di Kolose kelak akan mengalami tubuh kebangkitan. Kuasa kebangkitan Kristus mengakibatkan iman orang Kolose tidak sia-sia.

Kristus telah bangkit, maka orang-orang percaya mempunyai kesaksian yang lengkap dan tidak bisa diragukan sebab Kristus bangkit membuktikan kuasa-Nya ditengah-tengah dunia ini, maka orang-orang percaya ada sukacita yang besar kuasa Allah kekal dan terus memimpin menjaga dan memelihara orang percaya.

\section{Kesimpulan}

Orang Kristen yang baik adalah orang Kristen yang bukan saja mempertanggungjawabkan iman dan perbuatannya kepada Tuhan tetapi juga ia sanggup mempertanggungjawabkan ajarannya dengan baik dan benar kepada Tuhan dan sesama orang percaya. Dasar motivasi untuk melakukan ajaran yang benar adalah karena keyakinan yang benar terhadap pribadi Tuhan Yesus Kristus.

Itulah sebabnya Paulus menjelaskan dalam pasal 1 surat Kolose, pemahaman yang benar terhadap pribadi Tuhan Yesus Kristus akan menghasilkan teologi yang benar tentang Kristologi kita. Keyakinan terhadap kebenaran Kristus sebagai pencipta adalah pemahaman yang luar biasa terhadap pribadi kedua dari Allah Tritunggal, sebab keberadaanNya sebagai pencipta langit dan bumi ini tidak dapat dibantah oleh keakuratan informasi yang dilaporkan oleh Alkitab. KeberadaanNya sebagai yang kekal menujukkan bahwa Kristus adalah Allah, Dia bukan ada setelah dia lahir ke dunia ini, tetapi Ia telah ada sejak kekekalan masa lampau. Dalam keberadaanNya sebagai 
Allah yang kekal Ia layak disebut sebagai kepala dari tubuh yaitu jemaat sebagai tubuh Kristus. Kebenaran ini sangat amat penting karena fungsi Yesus Kristus sebagai kepala gereja yang memberi pertumbuhan kepada gereja sebagai anggota tubuh Kristus. Tanpa Kristus hidup orang percaya tidak dapat bertumbuh dalam iman yang benar. Hal lain yang sangat amat berarti dalam kehidupan umat manusia adalah Tuhan Yesus Kristus rela mati bagi umat manusia yang berdosa. KematianNya sangat berharga bagi manusia, demikian juga dengan kebangkitanNya sangat berarti bagi kebangkitan orang percaya di masa yang akan datang. Kebenaran ini tidak dapat disangkal apa lagi harus dibantah, sebab Ia adalah Allah yang olehNya semua mahluk di bumi ini maupun di sorga ada di bawah kuasaNya. Tidak ada ilah-ilah lain yang berkuasa selain Tuhan Yesus Kristus. Hal itu ditentukan jauh sebelum dunia diciptakan, bahwa Kristus akan pergi ke salib dan bahwa Ia akan menang atas maut dan dosa. Penyangkalan terhadap pribadi Kristus sebagai pencipta, sebagai yang kekal dan sebagai kepala tubuh serta Ia yang pertama bangkit dari orang mati adalah sesat. Setiap pribadi yang mengajarkan ajaran sesat layak mendapatkan perlawanan dan penolakan dalam komunitas orang percaya.

\section{Kepustakaan}

Bolkestein, M.H. Tafsiran Kolose. Jakarta: BPK Gunung Mulia, 1966.

Brill, J. Wesley. Dasar Yang Teguh. Bandung: Yayasan Kalam Hidup, tt.

Guthrie, Donald. Teologi Perjanjian Baru 1. Jakarta: BPK Gunung Mulia, 1992.

Guthrie, Donald. Tafsiran Alkitab Masa Kini 3. Jakarta: BPK Gunung Mulia, 1983.

Halley, Henry H.. Penuntun ke dalam Perjanjian Baru. Surabaya: Yakin, 1979.

Jaffray, R.A.. Tafsiran Kitab Kejadian Jilid 1. Bandung: Kalam Hidup, 1966.

Marantika, Chris, editor. Yesus Kristus Allah Manusia Sejati, Artikel Yesus Kristus

Kepala Tubuh. Surabaya: PASTI \& YAKIN, 1983
Tendean, F. Deimy. Diktat Kristologi. Pontianak: STT Kalimantan, semester VI,1993.

Thiessen, Henry C. Teologi Sistematika. Malang: Gandum Mas, 1992.

Widjana, Doreen. Kupasan Firman Allah Surat Kolose. Bandung: Lembaga LiteraturBaptis, 1994.

Wolvoord, John F.. Yesus Kristus Tuhan Kita. Surabaya: YAKIN,1969. 